\title{
Hypertonic saline reduces lipopolysaccharide- induced mouse brain edema through inhibiting aquaporin 4 expression
}

\author{
Cao $C^{1}$, Yu $X^{1}$, Liao $Z^{1}$, Zhu $N^{1}$, Huo $H^{1}$, Wang $M^{1}$, Ji $G^{1}$, She $H^{2,3}$, Luo $Z^{2^{*}}$ and Yue $S^{1 *}$
}

\begin{abstract}
Introduction: Three percent sodium chloride $(\mathrm{NaCl})$ treatment has been shown to reduce brain edema and inhibited brain aquaporin 4 (AQP4) expression in bacterial meningitis induced by Escherichia coli. Lipopolysaccharide (LPS) is the main pathogenic component of E. coli. We aimed to explore the effect of $3 \% \mathrm{NaCl}$ in mouse brain edema induced by LPS, as well as to elucidate the potential mechanisms of action.

Methods: Three percent $\mathrm{NaCl}$ was used to treat cerebral edema induced by LPS in mice in vivo. Brain water content, IL-1 $\beta$, TNF $\alpha$, immunoglobulin G (IgG), AQP4 mRNA and protein were measured in brain tissues. IL-1 $\beta, 3 \%$ $\mathrm{NaCl}$ and calphostin $\mathrm{C}$ (a specific inhibitor of protein kinase $\mathrm{C}$ ) were used to treat the primary astrocytes in vitro. AQP4 mRNA and protein were measured in astrocytes. Differences in various groups were determined by one-way analysis of variance.
\end{abstract}

Results: Three percent $\mathrm{NaCl}$ attenuated the increase of brain water content, IL-1 $\beta$, TNF $\alpha$, IgG, AQP4 mRNA and protein in brain tissues induced by LPS. Three percent $\mathrm{NaCl}$ inhibited the increase of AQP4 mRNA and protein in astrocytes induced by IL-1 in vitro. Calphostin C blocked the decrease of AQP4 mRNA and protein in astrocytes induced by $3 \% \mathrm{NaCl}$ in vitro.

Conclusions: Osmotherapy with $3 \% \mathrm{NaCl}$ ameliorated LPS-induced cerebral edema in vivo. In addition to its osmotic force, $3 \% \mathrm{NaCl}$ exerted anti-edema effects possibly through down-regulating the expression of proinflammatory cytokines (IL-1 $\beta$ and TNF $\alpha$ ) and inhibiting the expression of AQP4 induced by proinflammatory cytokines. Three percent $\mathrm{NaCl}$ attenuated the expression of AQP4 through activation of protein kinase $\mathrm{C}$ in astrocytes.

Keywords: hypertonic saline, lipopolysaccharide, brain edema, aquaporin 4, protein kinase C, interleukin-1 beta

\section{Introduction}

Hypertonic saline (HS) has been widely used in the treatment of patients with brain edema resulting from cerebral infarction, hemorrhage or traumatic brain injury [1-8], and the therapeutic efficiency of HS has also been proved by animal studies [9-13]. Previous reports suggested that HS was more effective in treating brain edema resulting from cerebral hemorrhage, ischemic or traumatic brain injury, as compared with equiosmolar

\footnotetext{
*Correspondence: luozq1962@163.com; shaojieyue@163.com 'Department of Pediatrics, Xiangya Hospital, Central South University, Xiangya Road, Changsha, Hunan, China 410008

${ }^{2}$ Department of Physiology, Xiangya Medical School, Central South

University, Xiangya Road, Changsha, Hunan, China 410013

Full list of author information is available at the end of the article
}

doses of mannitol, in animal studies $[9,12]$ and clinical trials [14-17]. Our previous study confirmed that adjunctive $3 \%(1,026 \mathrm{mOsm} / \mathrm{L}) \mathrm{NaCl}$ treatment reduced brain edema and attenuated brain damage with a superior effect over $20 \%$ mannitol in a rabbit bacterial meningitis model [11]. These studies indicated that HS has superior action to mannitol in the treatment of brain edema, in addition to its osmotic effect.

However, little was known of the action of HS besides its osmotic effect in the treatment of brain edema. HS has been suggested to be superior to mannitol as a hyperosmolar agent because it augments intravascular volume and cardiovascular performance in addition to causing 'dehydration' of the brain. In both animal and

\section{Biomed Central}


human studies, HS has been shown to produce a prolonged increase in intravascular volume and plasma volume expansion. In doing so, mean arterial pressure is increased and cerebra1 perfusion pressure is improved $[9,18]$. HS has also been shown to have anti-inflammatory effects, which, in turn, modulate blood-brain barrier (BBB) permeability $[7,19]$. Zeynalov et al. reported that $\mathrm{HS}$ attenuates $\mathrm{BBB}$ disruption depending on the presence of perivascular aquaporin 4 (AQP4) in postischemic cerebral edema[20]. AQP4 is the primary water channel found in the brain, which is expressed in astrocyte foot processes, in ependymal cells, and in subependymal astrocytes [21,22]. The expression of AQP4 is up-regulated in wild type mice and AQP4 null mice have significantly less brain edema in water intoxication cerebral edema, ischemic stroke and pneumococcal meningitis $[23,24]$. This suggests that AQP4 plays an important role in brain edema formation. Zeng et al. reported that $10 \% \mathrm{NaCl}$ can down-regulate expression of AQP4 in perivascular astrocytes in a rat cerebral ischemic edema model [25]. Recently, we reported that $3 \% \mathrm{NaCl}$ inhibited the up-regulation of brain AQP4 protein expression in bacterial meningitis induced by Escherichia coli in rabbits [11]. However, the mechanism of HS down-regulation of AQP4 expression still remains unclear. Lipopolysaccharide (LPS) is the main pathogenic component of E.coli Gram-negative bacterium. Administration of LPS to animals causes pathogenesis, mimicking what occurs in patients [26,27]. LPS can induce cerebral edema formation and up-regulate expression of brain AQP4 in the mouse [28]. Investigating the effect of HS on up-regulation of brain AQP4 during LPS-induced mice brain edema would provide clues to reveal the mechanism of HS down-regulation of brain AQP4 in bacterial meningitis.

Protein kinase C (PKC) is a family of serine- and threonine-specific protein kinases and plays an important role in the regulation of AQP4 expression. Activation of PKC with phorbol 12, 13-dibutyrate reduces the AQP4 water permeability of LLC-PK1 cells transfected with AQP4 cDNA constructs [29]. Treatment of rat astrocytes with phorbol ester 12-O-tetradecanoylphorbol 13-acetate, a PKC activator, causes a decrease in AQP4 mRNA and protein, which can be inhibited by PKC inhibitors [30]. AQP4 up-regulation and brain edema formation were attenuated by phorbol 12-myristate 13-acetate, a PKC activator, in a rat cerebral ischemia model [31-33]. HS increases total PKC activity and induces PKC $\alpha$, PKCd, and PKCe translocation from the cytosol to the membrane in NIH/3T3 cells [34]. We hypothesized that activation of PKC would contribute to down-regulation of AQP4 expression induced by HS.

Thus, in the present study we investigated the effects of $3 \% \mathrm{NaCl}$ on brain $\mathrm{AQP} 4$ expression in cerebral edema induced by LPS. Additionally, we also investigated the role of PKC in mediating the down-regulation of AQP4 expression induced by HS in primary astrocytes.

\section{Materials and methods}

\section{Animals and experimental groups}

KunMing mice were used for experiments at four weeks of age. The animals were maintained with 12-hour light and dark cycles with free access to food and water. The experimental design is shown in Figure 1. Mice were randomized into a control group, a LPS group and a HS group. The LPS group was given LPS (Sigma, Santa Clara, CA USA) as a single injection of $10 \mathrm{mg} / \mathrm{kg}$ i.p.. The $\mathrm{HS}$ group was given $3 \% \mathrm{NaCl}$ as a single injection of $20 \mathrm{ml} / \mathrm{kg}$ i.v. through the tail vein at 6 hours following injection of LPS, and the control group received $0.9 \%$ $\mathrm{NaCl}$ as control. The mice were sacrificed at 8 hours or 12 hours after injection of LPS. The animals were maintained and experiments were performed in accordance with the guidelines set by the Institutional Animal Care and Use Committee of University of Central South University. This research protocol was approved by the Ethics Committee of Xiangya Hospital of Central South University.

\section{Isolation and treatment of astrocytes}

Astrocytes were isolated from newborn Sprague-Dawley rats, using a method described by Nicholson and Renton [35]. Briefly, after removal of the meninges, brains of newborn Sprague-Dawley rats were disaggregated using nylon sieves (120 mm pore size) and seeded in 50-ml tissue culture flasks in (D)MEM containing 20\% heat-inactivated FCS. Growth medium was replaced on the third and sixth

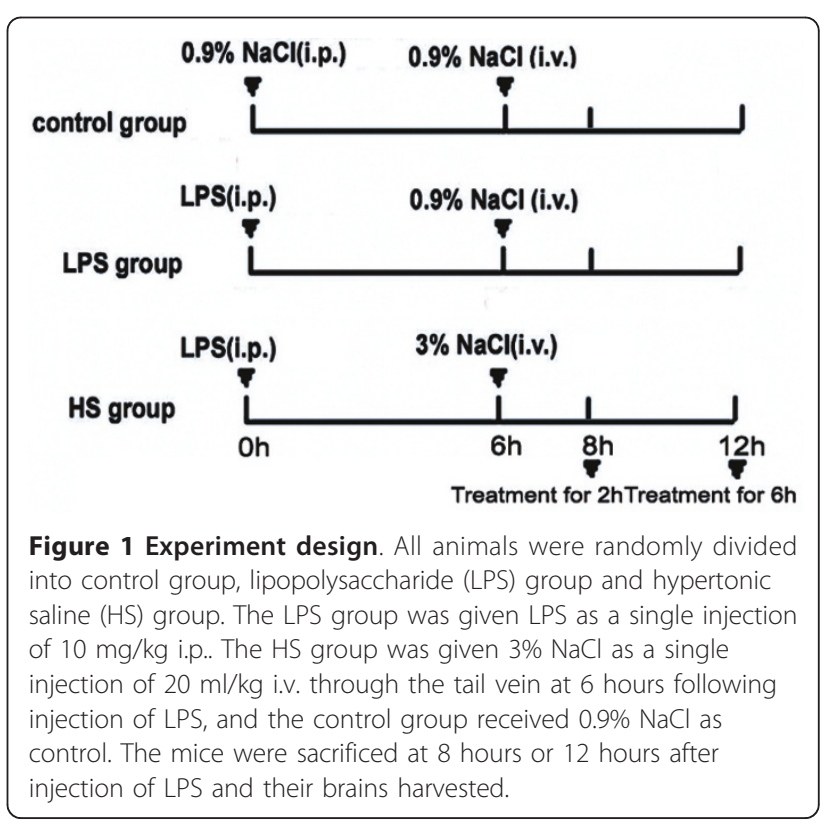


day with (D)MEM containing 20\% FCS. On day 10, subcultures were made by treating the cells with $0.25 \%$ trypsin:0.25\% ethylenediaminetetraacetic acid (EDTA) and, after washing, $1 \times 10^{6}$ cells $/ \mathrm{ml}$ plated in a $50-\mathrm{ml}$ tissue culture flask in (D)MEM with 10\% FCS. After a two-week incubation, cultures were approximately $90 \%$ to $95 \%$ confluent and contained predominantly astrocytes, with a minor contribution of microglia and oligodendrocytes (3\% and $2 \%$, respectively) as determined by immunocytochemistry using antibodies directed against the astrocyte marker glial fibrillary acid protein [36]. Then, the cells were randomly divided into control group, IL- $1 \beta$ group, IL- $1 \beta+$ HS group, IL-1 $1 \beta+$ calphostinC group and IL- $1 \beta+$ calphostinC + HS group. IL-1 $\beta$ group cells were incubated for six hours with fresh serum-free (D)MEM, containing IL-1 $(5 \mathrm{ng} / \mathrm{mL}$ ) (Recombinant Rat Interleukin-1 beta, ProSpec-Tany TechnoGene Ltd, Rehovot, Israel). IL-1 $\beta+$ HS group cells were incubated with fresh serum-free (D) MEM (containing IL-1 $5 \mathrm{ng} / \mathrm{mL}$ ) for 3 hours, $3 \% \mathrm{NaCl}$ for 15 minutes and fresh serum-free (D)MEM (containing IL-1 $5 \mathrm{ng} / \mathrm{mL}$ ) for 3 hours. Treatment of IL- $1 \beta+\mathrm{cal}-$ phostin C + HS group cells was the same as IL- $1 \beta+$ HS group cells, except for pretreatment with calphostin C (5 uM; Sigma) for 30 minutes before $3 \% \mathrm{NaCl}$. The control group received $0.9 \% \mathrm{NaCl}$ instead of $3 \% \mathrm{NaCl}$ and the fresh serum-free (D)MEM.

\section{Brain water content}

The brains were removed from the mice at the end of the experiment, weighed immediately and then kept at $106^{\circ} \mathrm{C}$ for 72 hours. The brains were weighed during this process at 48 hours and then again at 72 hours to make sure they had reached a consistent weight. Brain edema was estimated by comparing wet to dry weight ratios. Tissues were weighed with a scale to within $0.001 \mathrm{mg}$. The percentage of brain water in the tissue was calculated as (wet weight - dry weight) $\times 100 /$ wet weight.

\section{Detection of IL-1 $\beta$, TNF $\alpha$ protein and IgG by ELISA}

Briefly, animals were sacrificed at the end of the experiment and the whole brain from each animal was collected and weighed immediately. The brain tissue was homogenized with a glass homogenizer with the ratio of $100 \mathrm{mg}$ tissue: $1 \mathrm{ml}$ ice-cold PBS (pH 7.4) and centrifuged at $12,000 \mathrm{~g}$ for 20 minutes at $4^{\circ} \mathrm{C}$. IL- $1 \beta, \mathrm{TNF} \alpha$ protein and IgG in the brain tissues were detected by ELISA, following the manufacturer's instructions(Mouse IL-1 $\beta$ ELISA Kit/Mouse TNF $\alpha$ ELISA Kit/Mouse IgG ELISA Kit)(R\&D Systems Inc., Minneapolis, MN USA). Data were acquired using a 96-well plate reader. The contents are expressed as pg cytokines/g tissue or $\mathrm{ng}$ IgG/g tissue.

Brain edema could be due to both vasogenic and cytotoxic changes. The destruction of the BBB leads to vasogenic cerebral edema. To gain insight into this possibility, the $\mathrm{BBB}$ integrity was assessed by analyzing plasma IgG extravasation via ELISA. IgG is a plasma protein which exists mainly in the vascular. Abnormal permeability to IgG occurs after breakdown of the BBB and an increase of IgG in brain tissues can indicate breakdown of the BBB $[37,38]$.

\section{Western blotting}

Proteins were extracted from brain tissue using a total protein extraction kit (Pulilai Gene Technology Co., Ltd., Beijing, China) according to the manufacturer's protocol. Samples of supernatants containing protein were heated to $100^{\circ} \mathrm{C}$ for 5 minutes. Protein bands were electroblotted onto polyvinylindene difluoride membranes (Millipore, Boston, Massachusetts, USA). After transfer, the membranes were blocked with $5 \%$ nonfat milk in tris-buffered saline for 0.5 hours, and then incubated with the primary antibodies according to the manufacturer's recommendations. The primary antibodies used were as follows: AQP4 (rabbit polyclonal antibody 1:200, Beijing Biosynthesis Biotechnology Co., Ltd, Beijing, China), GAPDH (rabbit polyclonal antibody 1:3,000, Nanjing Genscript Corporation, Nanjing, China). After being washed three times with tris-buffered saline with $0.1 \%$ Tween-20, the membranes were incubated with the horseradish peroxidase (HRP)-conjugated secondary antibodies (1:5,000)(Nanjing Genscript Corporation) for 1 hour. Bands were visualized using the ECL kit per the manufacturer's manual(LumiGOLD ECL Western Blotting Detection Kit, SignaGen Laboratories, Gaithersburg, MD USA). The signal intensity of AQP4 levels in each group $(n=4)$ was measured.

\section{Real-time RT-PCR}

Total RNA was extracted from brain tissues or cells with trizol reagent (ShineGene, Shanghai, China) and contaminating genomic DNA was removed with RNasefree DNase I (ShineGene). RT-PCR was performed using a first-strand cDNA synthesis kit (ShineGene) following the manufacturer's instructions.

Quantitative RT-PCR was carried out on an FTC2000 real-time PCR system using a FastStart DNA Master plus SYBR Green I kit (ShineGene) following the manufacturer's instructions. The primers used were: AQP4 (213 bp), Forward: GCTTTCTGGAAGGCAGTCTCA, Reverse: GGCTACAGTCACAGCGGGA; IL-1(196 bp), Forward: GCTTCAGGCAGGCAGTATCA, Reverse: TGCAGTTGTCTAATGGG AACG; TNF $\alpha(156$ bp), Forward: TACTGAA CTTCGGGGTGATCG, Reverse: CCACTTGGTGGTTTGCTACG; $\beta$-actin(263 bp), Forward: GAGACCTTCAACACCCCAGC, Reverse: ATGTCACGCACGATTTC CC(Mouse); AQP4(138 bp), Forward: CGC CAAGTCCGTCTTCTACA, Reverse: GCCAGCAGTGAGGTTTCCAT, $\beta$-actin(150 bp), 
Forward: CCCATCTATGAGGGTTACGC, Reverse: TTTAATGTCACGCACGA TTTC(rat). The first segment of the amplification cycle consisted of a denaturation program at $94^{\circ} \mathrm{C}$ for 4 minutes. The second segment consisted of denaturation, primer annealing, elongation and a quantification program repeated for 35 cycles. The third segment consisted of a melting curve program. The final segment consisted of a cooling program at $72^{\circ} \mathrm{C}$. The expression of target genes was measured in tetramerous, and was normalized to $\beta$-actin. Gene expression was quantified using a modification of the 2(-Delta Delta $C(T)$ ) method as previously described [39].

\section{Flow cytometry}

With direct staining, astrocytes were incubated with AQP4-PE (Santa Cruz Biotechnology, Santa Cruz, CA USA) antibody, a monoclonal antibody conjugated to a fluorochrome phycoerythrin. This procedure was quick and direct; it merely involved a half-hour incubation of cells with antibody (at $4^{\circ} \mathrm{C}$ ), followed by several washes to remove weakly or nonspecifically bound antibodies. Cells thus treated were ready for flow analysis (although final fixation with $1 \%$ electron microscopic-grade formaldehyde provided a measure of biological safety and long-term stability). The mean fluorescence intensity of cells was measured in tetramerous with a flow cytometer (Beckman Coulter Co., Caguas, PR USA).

\section{Statistical analysis}

All values were presented as mean \pm S.E.M. Differences in various groups were determined by one-way analysis of variance. A value of $P<0.05$ was considered statistically significant.

\section{Results}

\section{Three percent $\mathrm{NaCl}$ attenuated brain edema induced} by LPS

To determine whether edema occurred in the brains of mice administered LPS, we measured the water content in the brains of control and LPS-treated mice. The brain water content (BWC) was significantly increased in LPStreated mice at 8 hours and 12 hours following LPS injection when compared with corresponding controls (Figure 2). Treatment with $3 \% \mathrm{NaCl}$ attenuated the increase in BWC at 8 hours and 12 hours after LPS injection (Figure 2). As shown in Figure 3, IgG in brain tissues increased in LPS-treated mice at 8 hours and 12 hours following LPS injection, but after treatment with $3 \% \mathrm{NaCl}$ IgG significantly decreased at 12 hours after LPS injection, compared with LPS-treated mice. The results suggest that $3 \% \mathrm{NaCl}$ alleviated the breakdown of the BBB induced by LPS.

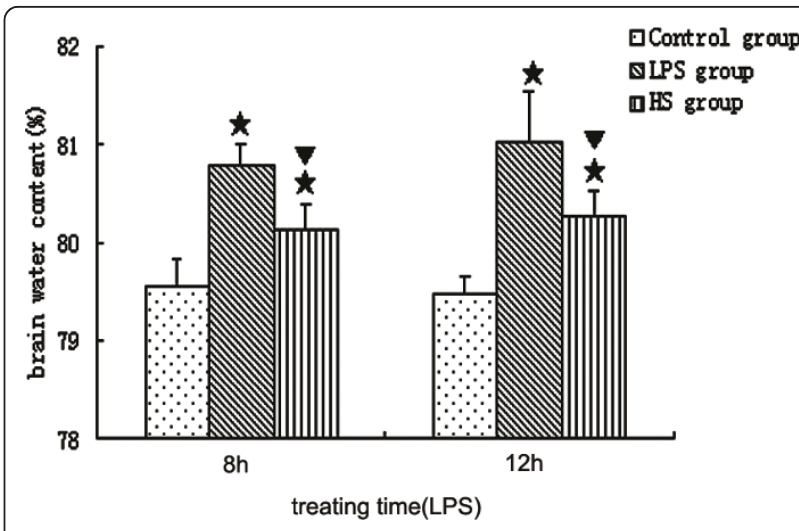

Figure 2 Brain water content in LPS group, HS group, and control group. The percentage of brain water content was significantly increased in LPS-treated mice at 8 hours and 12 hours following LPS injection when compared with the corresponding controls. However, treatment with $3 \% \mathrm{NaCl}$ attenuated the increase in brain water content at 8 hours and 12 hours after LPS injection. (single star) $P<0.05$ versus control group. (single triangle) $P<0.05$ versus LPS group. HS, hypertonic saline; LPS, lipopolysaccharide.

Three percent $\mathrm{NaCl}$ inhibited the increase of IL-1 $\beta$ and TNF $\alpha$ in brain tissues induced by LPS

IL- $1 \beta$ and TNF $\alpha$ are two important proinflammatory cytokines. As shown in Figure 4 (a, c), IL- $1 \beta$ and TNF $\alpha$ mRNA in brain tissues increased at 8 hours and 12 hours following LPS injection, compared with corresponding controls, but it significantly decreased in the mice at 8 hours and 12 hours following LPS injection after treatment with $3 \% \mathrm{NaCl}$. The ELISA results

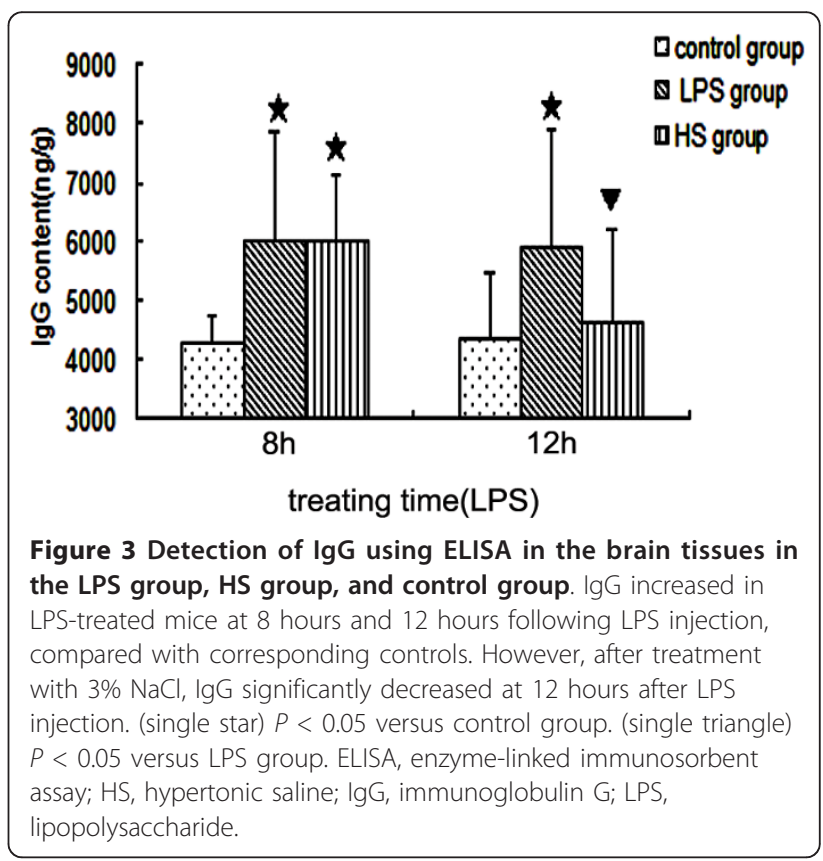




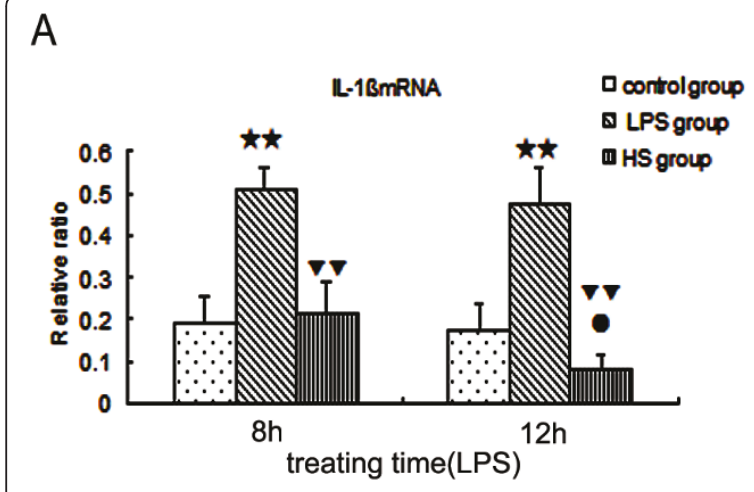

C

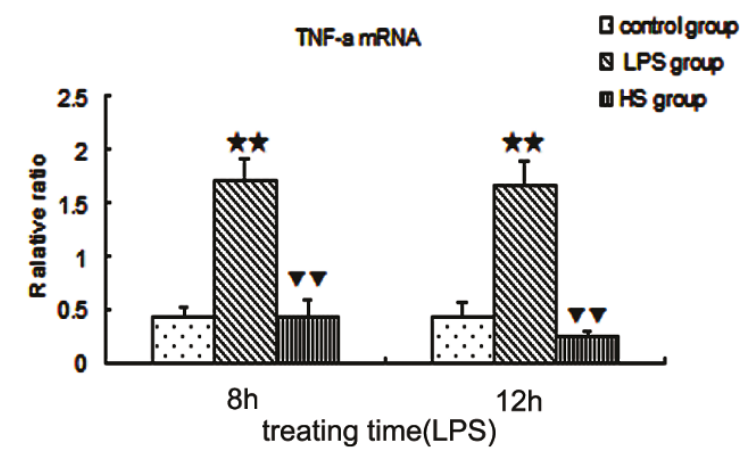

B

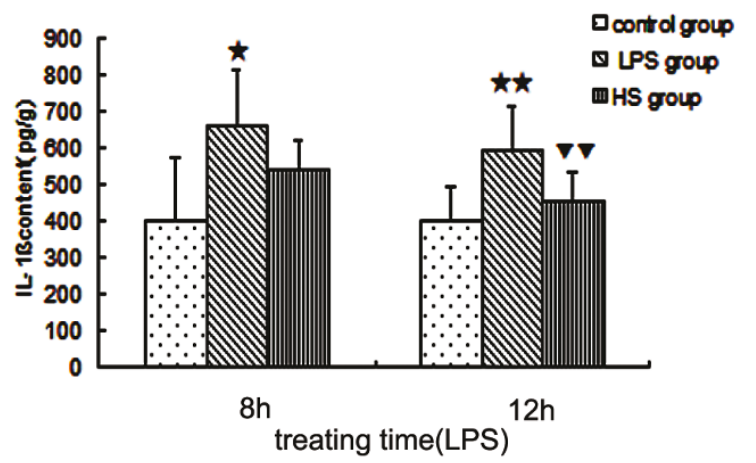

D

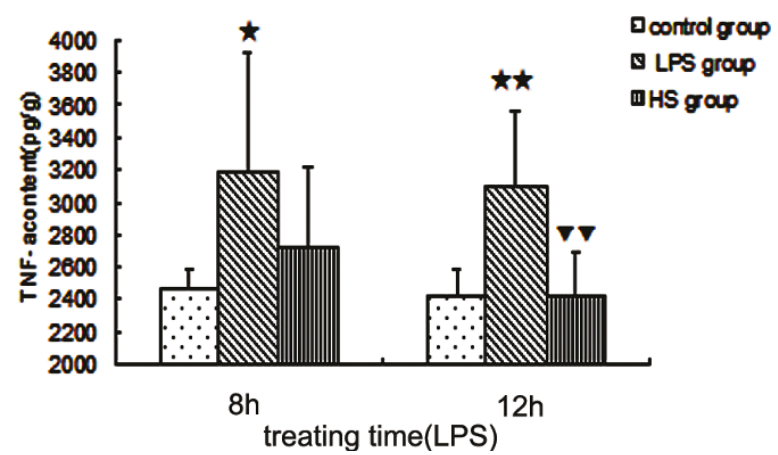

Figure 4 Expression of IL-1 $\beta$ and TNF $\alpha$ in the brain tissues in LPS group, HS group, and control group. IL-1 $\beta$ (a) and TNF $\alpha$ (c) mRNA was measured using real-time RT-PCR. $\beta$-actin was also included in the PCR reaction as a reference. IL-1 $\beta$ (b) and TNF $\alpha$ (d) proteins were measured using ELISA. (a, c) IL-1 $1 \beta$ and TNF $\alpha$ mRNA increased in LPS-treated mice at 8 hours and 12 hours following LPS injection, compared with the corresponding controls, but they significantly decreased in the mice at 8 hours and 12 hours following LPS injection after treatment with $3 \%$ $\mathrm{NaCl}$. (b, d) IL-1 $\beta$ and TNF $\alpha$ protein increased in LPS-treated mice at 8 hours and 12 hours following LPS injection, compared with the corresponding controls, but it significantly decreased in the mice at 12 hours following LPS injection after treatment with $3 \% \mathrm{NaCl}$ for 6 hours. (single star) $P<0.05$, (two stars) $P<0.01$ versus control group. (single triangle) $P<0.05$, (two triangles) $P<0.01$ versus LPS group. (single circle) $P<0.05$, versus 8 hour group. ELISA, enzyme-linked immunosorbent assay; HS, hypertonic saline; IL-1 1 , interleukin-1 beta; LPS, lipopolysaccharide; RT-PCR, reverse transcriptase-polymerase chain reaction; TNF $\alpha$, tumor necrosis factor alpha.

showed that the content of both IL-1 $\beta$ and TNF $\alpha$ in brain tissues was significantly increased at 8 hours and 12 hours following LPS injection, but IL-1 $\beta$ and TNF $\alpha$ significantly decreased in the mice at 12 hours following LPS injection after treatment with $3 \% \mathrm{NaCl}$ for 6 hours (Figure $4 \mathrm{~b}, \mathrm{~d}$ ). The results indicate that treatment with $3 \% \mathrm{NaCl}$ for 2 hours reduced the increase of IL- $1 \beta$ and TNF $\alpha$ mRNA in the brain tissues induced by LPS, and treatment with $3 \% \mathrm{NaCl}$ for 6 hours further reduced the increase of IL- $1 \beta$ and TNF $\alpha$ protein in the brain tissues induced by LPS.

Three percent $\mathrm{NaCl}$ blocked the increase of AQP4 mRNA and protein in brain tissues induced by LPS in vivo AQP4 expression was determined at the mRNA level by real-time RT-PCR and at the protein level by Western blotting. AQP4 mRNA and protein in brain tissues were significantly increased in LPS-treated mice at 8 hours and 12 hours following LPS injection, compared with the corresponding controls (Figure 5). After treatment with $3 \% \mathrm{NaCl}, \mathrm{AQP} 4 \mathrm{mRNA}$ was significantly decreased in brain tissues at 8 hours and 12 hours following LPS injection, compared with LPS-treated mice. AQP4 protein in the HS group was lower than in the corresponding LPS group at 12 hours following LPS injection after treatment with $3 \% \mathrm{NaCl}$ for 6 hours (Figure 5). The results indicate that LPS can up-regulate AQP4 mRNA and protein expression in brain tissues, and $3 \% \mathrm{NaCl}$ can inhibit AQP4 expression and reduce AQP4 mRNA and protein levels in brain tissues induced by LPS.

Three percent $\mathrm{NaCl}$ blocked the increase of AQP4 mRNA and protein in the primary astrocytes induced by IL-1 $\beta$ through activation of PKC in vitro

IL- $1 \beta$ is one of the major proinflammatory cytokines induced by LPS, and it can cause up-regulation of AQP4 in primary astrocytes [40]. To determine whether $3 \% \mathrm{NaCl}$ could directly antagonize the IL-1 $\beta$ action, we investigated the effect of $3 \% \mathrm{NaCl}$ on up-regulation of AQP4 induced by IL- $1 \beta$. As shown in Figure 5, IL- $1 \beta$ 


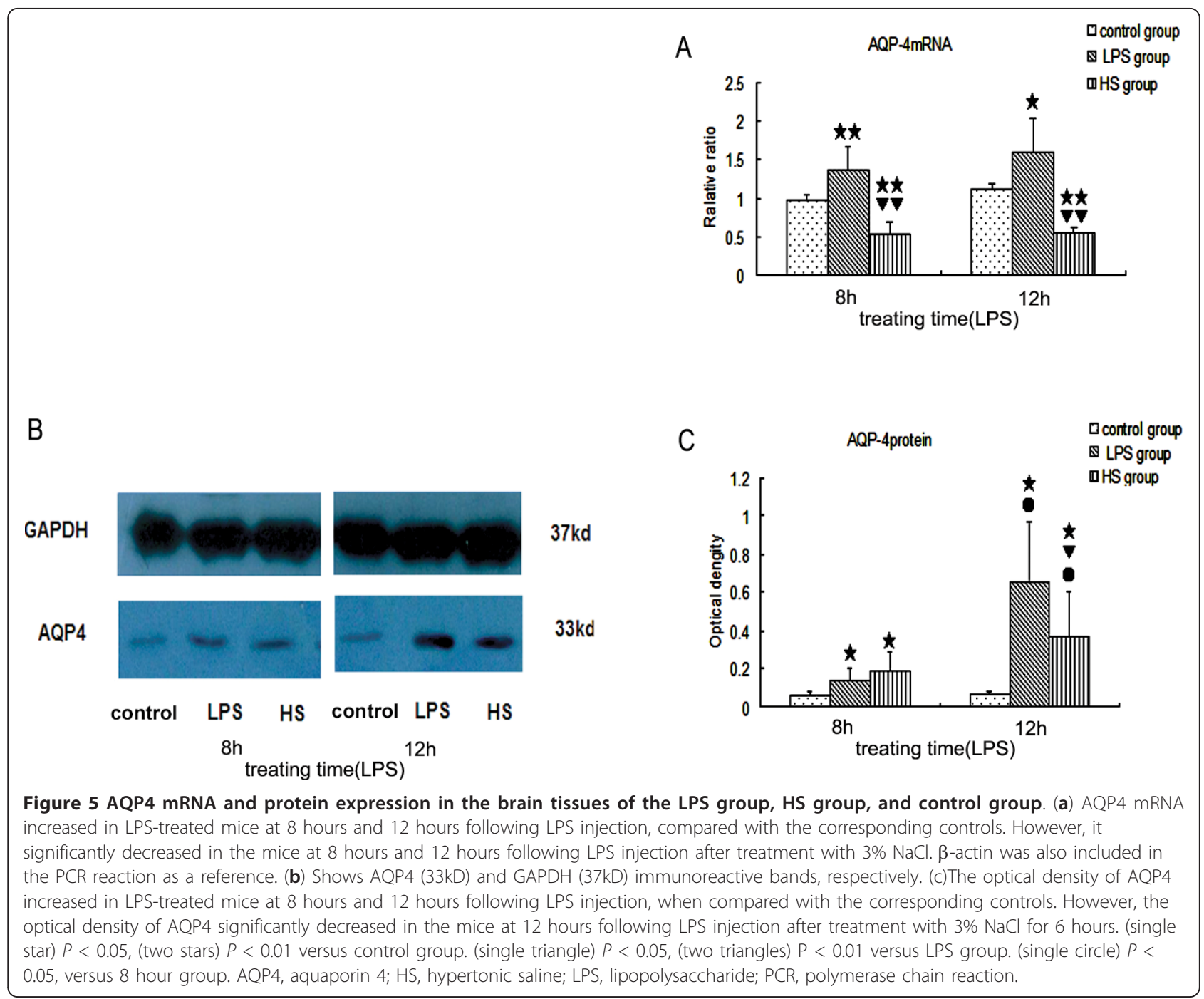

significantly increased AQP4 mRNA expression as determined by real-time-PCR and membrane protein level as determined by flow cytometry in IL-1 $\beta$-treated astrocytes. Three percent $\mathrm{NaCl}$ significantly decreased AQP4 mRNA and membrane protein levels in the IL-1 $\beta$ $+3 \% \mathrm{NaCl}$-treated astrocytes (Figure 6). In order to observe the possible mechanism of $3 \% \mathrm{NaCl}$ down-regulation of the expression of AQP4, we investigated the effect of calphostin $\mathrm{C}$, a specific inhibitor of $\mathrm{PKC}$, on the down-regulation of AQP4 induced by $3 \% \mathrm{NaCl}$. Pretreatment with calphostin $\mathrm{C}$ attenuated the decrease of AQP4 mRNA and protein in the primary astrocytes induced by $3 \% \mathrm{NaCl}$ (Figure 6).

\section{Discussion}

LPS is the critical pathogenic component of gram-negative bacteria. Administration of LPS to rats or mice induces up-regulated expression of IL-1 $\beta$ and TNF $\alpha$ in brain tissues, disruption of the $\mathrm{BBB}$ and brain edema formation [28,41-43]. Brain edema has traditionally been classified into three major types: cytotoxic, vasogenic and interstitial [44]. The mechanisms of brain edema induce by LPS are not fully elucidated. The proinflammatory cytokines of IL- $1 \beta$ and TNF $\alpha$ and complement cascade may play an important role in development of brain edema induced by LPS $[28,41,43]$. Hypertonic solutions are a mainstay of osmotherapy for cerebral edema. The accepted view is that the potent anti-edema effect of HS is affected primarily via egress of water from the interstitial and extracellular space into the intravascular compartment through an intact $\mathrm{BBB}$ $[11,45,46]$. In addition to this primary action, HS has been shown to exert beneficial non-osmotic cerebral effects. Our previous study confirmed that adjunctive $3 \% \mathrm{NaCl}$ treatment inhibited the expression of inflammatory factors in a rabbit bacterial meningitis model [11]. Our results confirm that intraperitoneal injection of LPS induced up-regulated expression of IL-1 $\beta$ and 


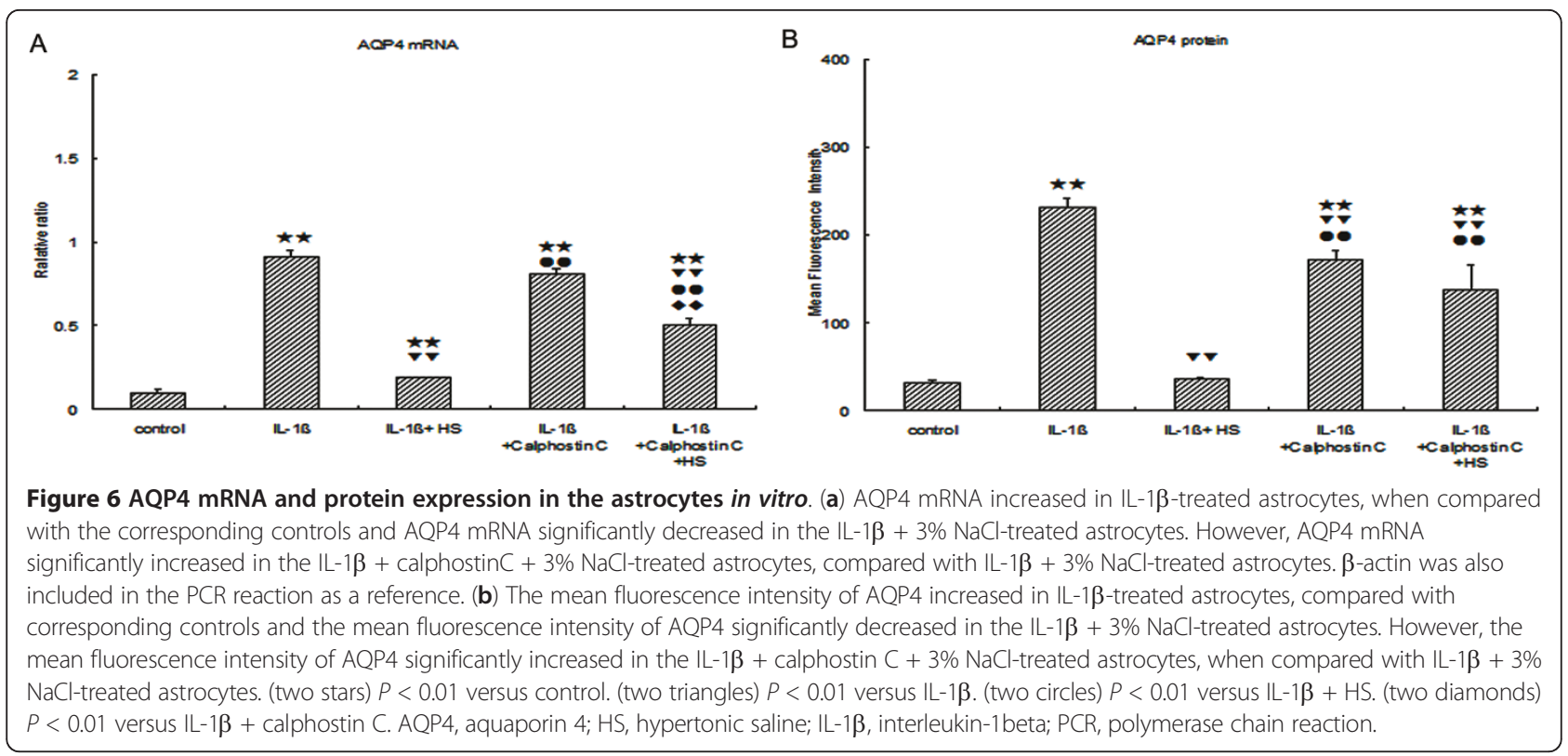

TNF $\alpha$, disruption of the BBB and brain edema. Adjunctive $3 \% \mathrm{NaCl}$ treatment for 2 hours could effectively reduce brain edema induced by LPS. After treatment with $3 \% \mathrm{NaCl}$ for 6 hours, IL-1 $\beta$ and TNF $\alpha$ mRNA and protein, and IgG in brain tissues decreased significantly and brain water content did not appear to rebound. We further confirmed that in addition to its osmotic force, $3 \% \mathrm{NaCl}$ could inhibit expression of IL-1 $\beta$ and TNFa, alleviate disruption of the $\mathrm{BBB}$ and reduce cerebral edema induced by LPS.

AQP4 is a water-channel protein predominantly expressed in astrocyte foot processes at the borders between the brain parenchyma and major fluid compartments, and in ependymal cells lining the ventricles in contact with cerebrospinal fluid in the brain $[22,47]$. This distribution suggests that AQP4 probably participates in water fluxes into and out of the brain parenchyma. AQP4 is up-regulated in the brain in ischemic brain edema $[48,49]$. AQP4 probably plays a critical role in reabsorption of cerebrospinal fluid and regulation of brain edema [50]. AQP4 null mice have lower mortality and are less prone to cytotoxic brain edema, including water intoxication cerebral edema [23], early focal cerebral ischemia [23] and bacterial meningitis [24]. Accordingly, overexpression of AQP4 in transgenic mice accelerates progression of cytotoxic brain swelling [51]. Down-regulation of AQP4 could be a way in which HS ameliorates cerebral edema $[11,20,25]$. AQP4 down-regulation slows the rate of water entry into the brain in cytotoxic edema. Our results show that injection of LPS could up-regulate expression of AQP4 mRNA and protein, which is consistent with previous reports $[28,37,43]$. Our results also showed for the first time that $3 \% \mathrm{NaCl}$ could down- regulate expression of $\mathrm{AQP} 4 \mathrm{mRNA}$ and protein in the brain edema induced by LPS. This may be another nonosmotic mechanism of HS in the treatment of cerebral edema induced by LPS.

The mechanism of HS down-regulation of AQP4 expression in cerebral edema is not yet known. Different authors have observed that HS could down-regulate the expression of AQP4 in cerebral edema induced by stroke [12], bacterial meningitis [11] or local cryoinjury [52]. However, they did not study the mechanism of HS down-regulation of AQP4 expression in cerebral edema. Proinflammatory cytokines are released as an important part of LPS induced brain injury. Previous study has shown that IL- $1 \beta$ induces the expression of AQP4 in primary astrocytes [40]. It is also reported that TNF $\alpha$ is a key mediator of brain edema formation, disruption of the $\mathrm{BBB}$ and up-regulation of AQP4 expression induced by LPS [28]. These studies suggest that LPS induced upregulated expression of AQP4 probably through increasing the production of IL-1 $1 \beta$ or TNF $\alpha$. Cuschieri et al. reported that HS preconditioning reduces TNF $\alpha$ production induced by LPS in alveolar macrophages [53]. Present results show that $3 \% \mathrm{NaCl}$ treatment reduced the up-regulation of AQP4 expression and reduced the production of IL-1 $\beta$ and TNF $\alpha$ induced by LPS in vivo. All of the above suggest that $3 \% \mathrm{NaCl}$ induced down-regulation of AQP4 expression and attenuated disruption of the BBB induced by LPS, probably through limiting the production of proinflammatory cytokines (IL-1 $\beta$ and TNF $\alpha$ ) in LPS-induced brain edema.

Astrocytes are the main cell type that swell in cytotoxic brain edema [54] and the cells are also the main cell type that express AQP4 in the brain [21]. We further 
investigated the effect of HS on AQP4 expression induced by IL-1 $\beta$ in astrocytes in vitro to explore the mechanism of HS down-regulation of brain AQP4. The results show that IL- $1 \beta$ significantly increased the AQP4 mRNA and membrane protein level in the astrocytes in vitro and that $3 \% \mathrm{NaCl}$ attenuated the increase of AQP4 mRNA and protein induced by IL-1 $\beta$. These results indicate that $3 \% \mathrm{NaCl}$ also directly antagonizes the IL- $1 \beta$ action of inhibiting up-regulated expression of AQP4 in the astrocytes. This may be another mechanism by which $3 \% \mathrm{NaCl}$ inhibits the up-regulation of AQP4 expression induced by LPS.

PKC serves as a second messenger for G-protein receptors that are coupled to the phosphoinositide pathway, causing either a transient rise in intracellular $\mathrm{Ca}^{2+}$, through inositol-triphosphate or activating PKC through diacylglycerol. Previous studies have shown that activation of PKC decreases the expression of AQP4 in rat astrocytes [30] and attenuates AQP4 up-regulation and brain edema formation [31-33].

Pretreatment of the cultured rat astrocytes with cycloheximide (an inhibitor of protein synthesis) or actinomycin D (an inhibitor of transcription) does not change the decrease in AQP4 mRNA induced by the phorbol ester 12-O-tetradecanoylphorbol 13-acetate [55]. It is suggested that $\mathrm{PKC}$ may be involved in AQP4 regulation on the transcriptional level, rather than affecting de novo protein synthesis or the stability of AQP4 mRNA. Tang et al. reported that thrombin inhibits AQP4 expression through a PKC-dependent pathway in cultured astrocytes [56]. It is reported that $3 \% \mathrm{NaCl}$ can activate PKC [34]. PKC mu performs a critical function in hypertonicityinduced heat shock protein 70 expression in NIH3T3 cells [57]. These findings suggest that the $3 \% \mathrm{NaCl}$ not only can activate PKC but also causes changes in gene expression mediated by the PKC in the cell. We used the PKC inhibitor of calphostin $C$ to further identify the role of PKC in HS down-regulation of the expression of $\mathrm{AQP} 4$. Our results demonstrated that calphostin $\mathrm{C}$ attenuated the decrease of AQP4 expression induced by $3 \%$ $\mathrm{NaCl}$ in the primary astrocytes. The results indicate that $3 \% \mathrm{NaCl}$ can attenuate the expression of AQP4 through activation of PKC.

\section{Conclusions}

This study shows that osmotherapy with $3 \% \mathrm{NaCl}$ ameliorated LPS-induced cerebral edema in vivo. In addition to its osmotic force, $3 \% \mathrm{NaCl}$ exerted anti-edema effects possibly through down-regulating the expression of proinflammatory cytokines (IL-1 $\beta$ and TNF $\alpha$ ) and inhibiting the expression of AQP4 induced by proinflammatory cytokines. Three percent $\mathrm{NaCl}$ attenuated the expression of AQP4 through activation of $\mathrm{PKC}$ in astrocytes. However, the optimal HS dose for reducing AQP4 expression, the pathway of activating PKC by HS and the significance of HS down-regulation of AQP4 in brain edema are to be further explored.

\section{Key messages}

- $3 \% \mathrm{NaCl}$ attenuated brain edema induced by LPS.

- $3 \% \mathrm{NaCl}$ inhibited the increase of IL-1 $\beta$ and TNF $\alpha$ in brain tissues induced by LPS.

- 3\% $\mathrm{NaCl}$ blocked the increase of AQP4 mRNA and protein in brain tissues induced by LPS in vivo.

- $3 \% \mathrm{NaCl}$ blocked the increase of AQP4 mRNA and protein in the primary astrocytes induced by IL-1 $\beta$ through activation of PKC in vitro.

\section{Abbreviations}

AQP4: aquaporin 4; BBB: blood-brain barrier; bp: base pair; BWC: brain water content; (D)MEM: (Dulbecco's) modified Eagle's medium; ELISA: enzymelinked immunosorbent assay; FCS: fetal calf serum; HRP: horseradish peroxidase; HS: hypertonic saline; IgG: immunoglobulin G; IL-1ß: interleukin-1 beta; LPS: lipopolysaccharide; NaCl: sodium chloride; PBS: phosphatebuffered saline; PKC: protein kinase C; RT-PCR: reverse transcriptasepolymerase chain reaction; TNFa: tumor necrosis factor alpha.

\section{Acknowledgements}

This study was supported by grants from the National Natural Science Foundation of China (No: 81070970), Specialized Research Fund for the Doctoral Program of Higher Education (No: 20090162110016), the Open-End Fund for the Valuable and Precision Instruments of Central South University and Research Fund of Development and Research Fund of Development and Reform Commission of Hunan Province (No:2010).

\section{Author details}

'Department of Pediatrics, Xiangya Hospital, Central South University, Xiangya Road, Changsha, Hunan, China 410008. ${ }^{2}$ Department of Physiology, Xiangya Medical School, Central South University, Xiangya Road, Changsha, Hunan, China 410013. ${ }^{3}$ Department of Pharmacology, Emory University, 1518 Clifton Road Northeast, Atlanta, GA, USA GA 30322.

\section{Authors' contributions}

CC participated in ELISA, flow cytometry, western blotting and real-time RTPCR detection and drafted the manuscript. ZCL, NZ, HH and MW participated in the isolation and treatment of astrocytes and detection of brain water content. GJ and HS participated in the design of the study and performed the statistical analysis. SY, ZL and XY conceived of the study, and participated in its design and coordination and helped to draft the manuscript. All authors read and approved the final manuscript.

\section{Competing interests}

The authors declare that they have no competing interests.

Received: 26 March 2012 Revised: 13 June 2012

Accepted: 4 October 2012 Published: 4 October 2012

\section{References}

1. Schwarz S, Schwab S, Bertram M, Aschoff A, Hacke W: Effects of hypertonic saline hydroxyethyl starch solution and mannitol in patients with increased intracranial pressure after stroke. Stroke 1998, 29:1550-1555

2. Schwarz S, Georgiadis D, Aschoff A, Schwab S: Effects of hypertonic (10\%) saline in patients with raised intracranial pressure after stroke. Stroke 2002, 33:136-140.

3. Suarez Jl, Qureshi Al, Parekh PD, Razumovsky A, Tamargo RJ, Bhardwaj A, Ulatowski JA: Administration of hypertonic (3\%) sodium chloride/acetate in hyponatremic patients with symptomatic vasospasm following subarachnoid hemorrhage. J Neurosurg Anesthesiol 1999, 11:178-184. 
4. Hartl R, Ghajar J, Hochleuthner H, Mauritz W: Hypertonic/hyperoncotic saline reliably reduces ICP in severely head-injured patients with intracranial hypertension. Acta Neurochir Supp/ 1997, 70:126-129.

5. Shackford SR, Bourguignon PR, Wald SL, Rogers FB, Osler TM, Clark DE: Hypertonic saline resuscitation of patients with head injury: a prospective, randomized clinical trial. J Trauma 1998, 44:50-58.

6. Qureshi Al, Suri MF, Ringer AJ, Guterman LR, Hopkins LN: Regional intraparenchymal pressure differences in experimental intracerebral hemorrhage: effect of hypertonic saline. Crit Care Med 2002, 30:435-441.

7. Ziai WC, Toung TJ, Bhardwaj A: Hypertonic saline: first-line therapy for cerebral edema? J Neurol Sci 2007, 261:157-166.

8. Peterson B, Khanna S, Fisher B, Marshall L: Prolonged hypernatremia controls elevated intracranial pressure in head-injured pediatric patients. Crit Care Med 2000, 28:1136-1143.

9. Qureshi Al, Wilson DA, Traystman RJ: Treatment of elevated intracranial pressure in experimental intracerebral hemorrhage: comparison between mannitol and hypertonic saline. Neurosurgery 1999, 44:1055-1063; discussion 1063-1054

10. Heimann A, Takeshima T, Alessandri B, Noppens R, Kempski O: Effects of hypertonic/hyperoncotic treatment after rat cortical vein occlusion. Crit Care Med 2003, 31:2495-2501

11. Liu S, Li L, Luo Z, Wang M, She H, Yu X, Deng X, Huang F, Shang L, Jian C, Ji G, Yue S: Superior effect of hypertonic saline over mannitol to attenuate cerebral edema in a rabbit bacterial meningitis model. Crit Care Med 2011, 39:1467-1473.

12. Zeng HK, Wang $Q S$, Deng $Y Y$, Jiang $W Q$, Fang $M$, Chen $C B$, Jiang $X: A$ comparative study on the efficacy of $10 \%$ hypertonic saline and equal volume of $20 \%$ mannitol in the treatment of experimentally induced cerebral edema in adult rats. BMC Neurosci 2010, 11:153.

13. da Silva JC, de Lima Fde M, Valenca MM, de Azevedo Filho HR: Hypertonic saline more efficacious than mannitol in lethal intracranial hypertension model. Neurol Res 2010, 32:139-143.

14. Vialet R, Albanese J, Thomachot L, Antonini F, Bourgouin A, Alliez B, Martin C: Isovolume hypertonic solutes (sodium chloride or mannitol) in the treatment of refractory posttraumatic intracranial hypertension: 2 $\mathrm{mL} / \mathrm{kg} 7.5 \%$ saline is more effective than $2 \mathrm{~mL} / \mathrm{kg} 20 \%$ mannitol. Crit Care Med 2003, 31:1683-1687.

15. Battison C, Andrews PJ, Graham C, Petty T: Randomized, controlled trial on the effect of a $20 \%$ mannitol solution and a $7.5 \%$ saline $/ 6 \%$ dextran solution on increased intracranial pressure after brain injury. Crit Care Med 2005, 33:196-202; discussion 257-198.

16. Francony G, Fauvage B, Falcon D, Canet C, Dilou H, Lavagne P, Jacquot C, Payen JF: Equimolar doses of mannitol and hypertonic saline in the treatment of increased intracranial pressure. Crit Care Med 2008, 36:795-800.

17. Kamel H, Navi BB, Nakagawa K, Hemphill JC, Ko NU: Hypertonic saline versus mannitol for the treatment of elevated intracranial pressure: a meta-analysis of randomized clinical trials. Crit Care Med 2011, 39:554-559.

18. Knapp JM: Hyperosmolar therapy in the treatment of severe head injury in children: mannitol and hypertonic saline. AACN Clin Issues 2005, 16:199-211.

19. Chen $\mathrm{CH}$, Toung TJ, Sapirstein A, Bhardwaj A: Effect of duration of osmotherapy on blood-brain barrier disruption and regional cerebral edema after experimental stroke. J Cereb Blood Flow Metab 2006, 26:951-958.

20. Zeynalov E, Chen CH, Froehner SC, Adams ME, Ottersen OP, AmiryMoghaddam M, Bhardwaj A: The perivascular pool of aquaporin-4 mediates the effect of osmotherapy in postischemic cerebral edema. Crit Care Med 2008, 36:2634-2640.

21. Nielsen S, Nagelhus EA, Amiry-Moghaddam M, Bourque C, Agre P, Ottersen OP: Specialized membrane domains for water transport in glial cells: high-resolution immunogold cytochemistry of aquaporin-4 in rat brain. J Neurosci 1997, 17:171-180.

22. Rash JE, Yasumura T, Hudson CS, Agre P, Nielsen S: Direct immunogold labeling of aquaporin- 4 in square arrays of astrocyte and ependymocyte plasma membranes in rat brain and spinal cord. Proc Natl Acad Sci USA 1998, 95:11981-11986.

23. Manley GT, Fujimura M, Ma T, Noshita N, Filiz F, Bollen AW, Chan P, Verkman AS: Aquaporin-4 deletion in mice reduces brain edema after acute water intoxication and ischemic stroke. Nat Med 2000, 6:159-163.
24. Papadopoulos MC, Verkman AS: Aquaporin-4 gene disruption in mice reduces brain swelling and mortality in pneumococcal meningitis. J Biol Chem 2005, 280:13906-13912.

25. Zeng HK, Wang QS, Deng $Y Y$, Fang $M$, Chen $C B$, Fu YH, Jiang WQ, Jiang $X$ Hypertonic saline ameliorates cerebral edema through downregulation of aquaporin-4 expression in the astrocytes. Neuroscience 2010, 166:878-885.

26. Gardenfors A, Nilsson F, Skagerberg G, Ungerstedt U, Nordstrom CH: Cerebral physiological and biochemical changes during vasogenic brain oedema induced by intrathecal injection of bacterial lipopolysaccharides in piglets. Acta Neurochir (Wien) 2002, 144:601-608; discussion 608-609.

27. Radzivil GG, Beloborodov VB, Bronikin lu V: Hemodynamics and rheologic properties of the blood in meningococcemia associated with meningitis and complicated by septic shock and intracranial hypertension. Anesteziol Reanimatol 1990, 2:28-33.

28. Alexander JJ, Jacob A, Cunningham P, Hensley L, Quigg RJ: TNF is a key mediator of septic encephalopathy acting through its receptor, TNF receptor-1. Neurochem Int 2008, 52:447-456.

29. Zelenina M, Zelenin S, Bondar AA, Brismar H, Aperia A: Water permeability of aquaporin- 4 is decreased by protein kinase $C$ and dopamine. Am J Physiol Renal Physiol 2002, 283:F309-318.

30. Yamamoto N, Sobue K, Miyachi T, Inagaki M, Miura Y, Katsuya H, Asai K: Differential regulation of aquaporin expression in astrocytes by protein kinase C. Brain Res Mol Brain Res 2001, 95:110-116.

31. Kleindienst A, Fazzina G, Amorini AM, Dunbar JG, Glisson R, Marmarou A: Modulation of AQP4 expression by the protein kinase $C$ activator, phorbol myristate acetate, decreases ischemia-induced brain edema. Acta Neurochir Suppl 2006, 96:393-397.

32. Okuno K, Taya K, Marmarou CR, Ozisik P, Fazzina G, Kleindienst A, Gulsen S, Marmarou A: The modulation of aquaporin-4 by using PKC-activator (phorbol myristate acetate) and V1a receptor antagonist (SR49059) following middle cerebral artery occlusion/reperfusion in the rat. Acta Neurochir Supp/ 2008, AQP4, aquaporin 4; HS, hypertonic saline; LPS, lipopolysaccharide; PCR, polymerase chain reaction.

33. Fazzina G, Amorini AM, Marmarou CR, Fukui S, Okuno K, Dunbar JG, Glisson R, Marmarou A, Kleindienst A: The protein kinase $C$ activator phorbol myristate acetate decreases brain edema by aquaporin 4 downregulation after middle cerebral artery occlusion in the rat. J Neurotrauma 2010, 27:453-461.

34. Zhuang S, Hirai SI, Ohno S: Hyperosmolality induces activation of CPKC and $\mathrm{nPKC}$, a requirement for ERK1/2 activation in $\mathrm{NIH} / 3 \mathrm{~T} 3$ cells. Am J Physiol Cell Physiol 2000, 278:C102-109.

35. Nicholson TE, Renton KW: Modulation of cytochrome P450 by inflammation in astrocytes. Brain Res 1999, 827:12-18.

36. Hertz L: Calcium accumulation and calcium effects in astrocytes in primary cultures. Acta Physiol Scand Supp/ 1989, 582:33.

37. Tomas-Camardiel M, Venero JL, Herrera AJ, De Pablos RM, Pintor-Toro JA, Machado A, Cano J: Blood-brain barrier disruption highly induces aquaporin-4 mRNA and protein in perivascular and parenchymal astrocytes: protective effect by estradiol treatment in ovariectomized animals. J Neurosci Res 2005, 80:235-246.

38. Butt OI, Buehler PW, D'Agnillo F: Blood-brain barrier disruption and oxidative stress in guinea pig after systemic exposure to modified cellfree hemoglobin. Am J Pathol 2011, 178:1316-1328.

39. Livak KJ, Schmittgen TD: Analysis of relative gene expression data using real-time quantitative PCR and the 2(-Delta Delta $C(T))$ Method. Methods 2001, 25:402-408.

40. Ito H, Yamamoto $N$, Arima $H$, Hirate $H$, Morishima $T$, Umenishi F, Tada T, Asai K, Katsuya H, Sobue K: Interleukin-1 beta induces the expression of aquaporin-4 through a nuclear factor-kappaB pathway in rat astrocytes. J Neurochem 2006, 99:107-118.

41. Cai Z, Pang $Y$, Lin S, Rhodes PG: Differential roles of tumor necrosis factor-alpha and interleukin-1 beta in lipopolysaccharide-induced brain injury in the neonatal rat. Brain Res 2003, 975:37-47.

42. Pang Y, Cai Z, Rhodes PG: Disturbance of oligodendrocyte development, hypomyelination and white matter injury in the neonatal rat brain after intracerebral injection of lipopolysaccharide. Brain Res Dev Brain Res 2003, 140:205-214.

43. Jacob A, Hensley LK, Safratowich BD, Quigg RJ, Alexander JJ: The role of the complement cascade in endotoxin-induced septic encephalopathy. Lab Invest 2007, 87:1186-1194. 
44. Harukuni I, Kirsch JR, Bhardwaj A: Cerebral resuscitation: role of osmotherapy. J Anesth 2002, 16:229-237.

45. Forsyth LL, Liu-DeRyke X, Parker D Jr, Rhoney DH: Role of hypertonic saline for the management of intracranial hypertension after stroke and traumatic brain injury. Pharmacotherapy 2008, 28:469-484.

46. White $H$, Cook D, Venkatesh B: The role of hypertonic saline in neurotrauma. Eur J Anaesthesiol Suppl 2008, 42:104-109.

47. Frigeri A, Gropper MA, Turck CW, Verkman AS: Immunolocalization of the mercurial-insensitive water channel and glycerol intrinsic protein in epithelial cell plasma membranes. Proc Natl Acad Sci USA 1995, 92:4328-4331.

48. Ribeiro Mde C, Hirt L, Bogousslavsky J, Regli L, Badaut J: Time course of aquaporin expression after transient focal cerebral ischemia in mice. J Neurosci Res 2006, 83:1231-1240.

49. Yang M, Gao F, Liu H, Yu WH, Sun SQ: Temporal changes in expression of aquaporin-3, $-4,-5$ and -8 in rat brains after permanent focal cerebral ischemia. Brain Res 2009, 1290:121-132.

50. King LS, Agre P: Pathophysiology of the aquaporin water channels. Annu Rev Physiol 1996, 58:619-648.

51. Yang B, Zador Z, Verkman AS: Glial cell aquaporin-4 overexpression in transgenic mice accelerates cytotoxic brain swelling. J Biol Chem 2008, 283:15280-15286.

52. Jiang W, Cao WJ, Zhang YK, Wei XY, Kuang F: Bolus injection of hypertonic solutions for cerebral edema in rats: challenge of homeostasis of healthy brain. Neurosci Lett 2012, 509:44-49.

53. Cuschieri J, Gourlay D, Garcia I, Jelacic S, Maier RV: Hypertonic preconditioning inhibits macrophage responsiveness to endotoxin. J Immunol 2002, 168:1389-1396.

54. Kimelberg HK: Current concepts of brain edema. Review of laboratory investigations. J Neurosurg 1995, 83:1051-1059.

55. Nakahama K, Nagano M, Fujioka A, Shinoda K, Sasaki H: Effect of TPA on aquaporin 4 mRNA expression in cultured rat astrocytes. Glia 1999, 25:240-246.

56. Tang Y, Cai D, Chen Y: Thrombin inhibits aquaporin 4 expression through protein kinase C-dependent pathway in cultured astrocytes. J Mol Neurosci 2007, 31:83-93.

57. Lim YS, Lee JS, Huang TQ, Seo JS: Protein kinase Cmu plays an essential role in hypertonicity-induced heat shock protein 70 expression. Exp Mol Med 2008, 40:596-606.

doi:10.1186/cc11670

Cite this article as: $C$ et al:: Hypertonic saline reduces

lipopolysaccharide-induced mouse brain edema through inhibiting

aquaporin 4 expression. Critical Care 2012 16:R186.

\section{Submit your next manuscript to BioMed Central and take full advantage of:}

- Convenient online submission

- Thorough peer review

- No space constraints or color figure charges

- Immediate publication on acceptance

- Inclusion in PubMed, CAS, Scopus and Google Scholar

- Research which is freely available for redistribution

Submit your manuscript at www.biomedcentral.com/submit 